\title{
Economic aspects of applying hail protection nets in apple plantationsf
}

\author{
Apáti, F. ${ }^{1}$ \& Soltész, M. ${ }^{2}$ \\ ${ }^{1}$ University of Debrecen Centre for Agricultural and Applied Economic Sciences \\ H-4032 Debrecen Böszörményi út 138., Hungary \\ ${ }^{2}$ Collage of Kecskemét, Faculty of Horticulture, H-600 Kecskemét Erdei Ferenc tér 1-3.
}

\begin{abstract}
Summary: The up to date intense apple growing in Hungary is capable to produce yearly about 500-1000 thousand Ft/ha income, which means that the investment of 4 000-5 000 thousand Ft is returned by producing 10-20\% net income. The economic balance may, however, be upset by the damage caused by hail, quantitative and qualitative, with an apparently increasing frequency experienced in each third or fourth year. Estimates prove that each hail causing 50\% damage may reduces the income proportionately to the capital by $1.5-2.0$ percent points, which means a serious threat for the economy of apple production. According to calculations, a plantation producing $30-40 \mathrm{t} / \mathrm{ha}$ yields would not be able to raise incomes compensating the investment of 7.0-10.0 million Ft/ha, let alone the frequencies of hail damages. Consequently, 50-60 t/ha yields are needed to become successful, and in planning of new plantations those high yields are aimed with hail nets. An additional difficulty is represented by a lack of financial resources to install hail protection nets.
\end{abstract}

Key words: hail, hail-damage, hail protection net, apple profitability, economy of investment

\section{Introduction}

Hails are dangerous sources of damage in horticultural production. The immediate danger is the scares caused by mechanical knocks appearing on the fruits, which may annihilate the market value of produces. Moreover, serious breaks may occur also on the woody parts of the fruit trees, which reduce the future yields of subsequent, even the third, year. Additional indirect economic consequences of a hail are expected as explained below:

- wounds appearing on all parts of the trees require hygienic care, which means expenses,

- productivity of tending and harvesting works declines and the specific costs for the scared fruits increased by the necessity of preliminary selection on the tree or later in the warehouse. Total destruction of fruits means the sparing of harvesting costs but also a total loss of income,

- in spite of careful election, wounds on the fruit may start decay threatening the healthy fruits too and causing further deficits during the sales' season,

- the shortage of goods leaves the storing capacity unutilized increasing the prime costs substantially,

- mainly, in larger enterprises, the lack of goods may cause loss of markets on the long run.

As expected, the changes in global climatic conditions are promising weather excesses, i.e. higher frequencies and intensities of hails. Interests to develop technologies for protecting plantations against damages caused by hail are increasing in the fruit growing branch. As the first approach to solve the question, we may distinguish two alternatives, one is the control on the level of enterprises, whereas control on the community level. Within the former level there are the hail protecting nets and the hail protecting cannons. With adequate outfits, they are to be solved on the spot by high costs to be economized from the income. The technologies on the community level require common actions on a whole region or even on a country. At the moment, three alternative technologies are known: the rockets, soil-generators and airplanes.

Let alone the hail protecting methods on the level of enterprises, an accepted way to cope with hail damages is the insurance. However, it does not prevent damages, it is designed to moderate the economic consequences of a physically existing damage or some of its components explained above. As a matter of fact, the insurance charges are expensive and tend to become even more expensive, approaching the $15-20 \%$ of the value insured. Insurance cannot be effected, where the hails are frequent. On the contrary, hail protection systems (involving both on the level of plantations or even of community) are aimed to prevent damages with of its consequences.

Considering the fact that an enterprise may choose from the first category, we are dealing with the use of hail protective nets.

\section{Materials and methods}

The method of our analysis is based on raising primary data in farms on costs and incomes - and also on secondary 
data - as by modelling with simulation. According to our point of view, profitability means profit on the long run, where the incomes of the fruiting plantations ought to produce during some years the whole sum of investments at least, taking into account the incomes of all years as they were from the present year (because interests of past years are considered to diminish with time). The economic parameters applied are the following:

Net value of income (NPV) calculated for 15 years. The accumulated sum of yields and the incomes of each year are compared and discounted with present value of the

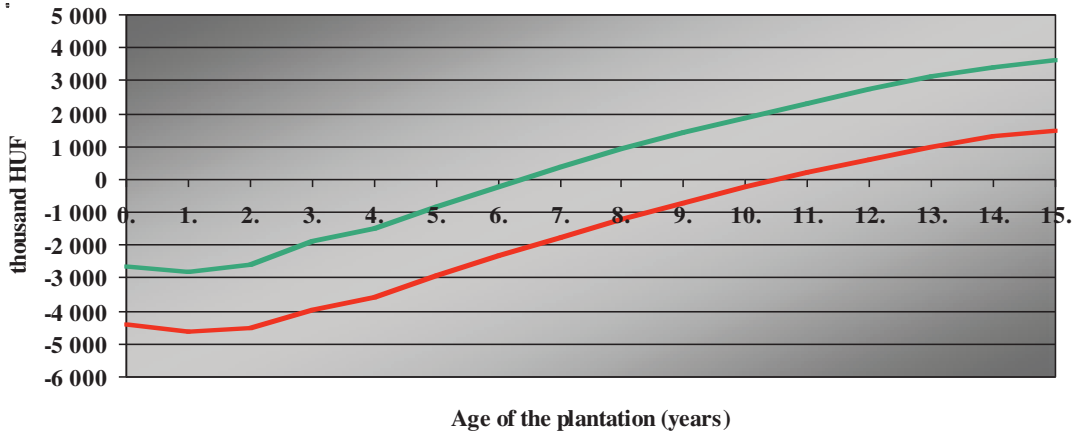

Planting of the plantation without subsidy —Planting of the plantation with subsidy (40\%)

Figure 1. Profitability and the time of returns of an intensive apple plantation without hail nets and hail damages (the present net value of accumulated income (NPV), in thousand Ft/ha) plantation in order to show the interest of the locked-up capital. As income we consider the difference between the actual earnings and the effective expenses.

The time of returns (DPP) is the year, when the accumulated incomes - according to the former point - (reckoned on the present value) reached, or trespassed, the 0 value. That means the return of the invested capital, i.e. all expenses of investments and farming costs of the training and bearing years.

The profitability proportional to the capital (IRR) expresses how much interests have to be asked for investments if deposited in the bank for the lifetime of the plantation (15 years), to outstrip the accumulated returns of the plantation during that time on the present value of money.

\section{Results}

In Figure 1, we see the data of an intensive apple plantation without hail net (M9 stocks, 4 x 1 m planting order, 2500 tree/ha density, set as saplings, supporting system with wires, dripping irrigation, in bearing years yielding $40 \mathrm{t} / \mathrm{ha}$ with $85 \%$ of best quality). The economic parameters are considered as a case of comparison with the supposition that no hail damage occurred. We have to remark that it is not a concrete case but throughout realistic. In the year of planting (year 0) 4.5 million $\mathrm{Ft}$ was the investment. In the first years (1-2), the graph shows further expenses as long the yields start to compensate for current expenses. Subsequently, some yields produce incomes from sales around $900000 \mathrm{Ft} / \mathrm{ha} /$ year (in this phase, the cca. $300000 \mathrm{Ft}$ amortisation should not be considered). If subsidies were not used for the planting, the return of the investments would be reached in the $11^{\text {th }}$ year, when the IRR (profitability proportional to the capital) will be $10.8 \%$. A subsidy of $40 \%$ for the investment would much help because only $60 \%$ of the investment is required from the own capital, consequently, the year of positive income will be shortened to 7, and IRR thousand Ft/ha) (profitability proportional to the capital) will be $20.2 \%$, which is very good.

The economic situation is highly influenced by the quantitative and qualitative losses caused by a hail. If we consider a case of plantation without subsidies, a single hail damage (causing 50\% losses of income) during the fruit bearing period could delay the year of return of investments to the $12^{\text {th }}$ or $13^{\text {th }}$ year instead of the $11^{\text {th }}$, moreover, such hail damages occurring three times during the 15 years, would jeopardize the profitability of the whole enterprise.

Plantings with the aid of subsidies have clearly more chances keeping to be profitable even after three damaged (each by 50\%) years, the year of returning investments will be delayed by $2-3$ years only instead of 7 years. Generally, each hail causing $50 \%$ damage during the fruiting period will cause a loss of $1.5-2.0 \%$ from the IRR (profitability proportional to the capital). The subsidies given for investments in planting

The advantage of hail protecting nets is - if the construction is stable - practically that hails almost of highest intensity could be averted, so its efficiency is nearly $100 \%$. The disadvantage is - however - its enormous cost, i.e. 3-4 million Ft/ha. No additional expenses are needed, but its benefit depends on the frequency of hails during its use.

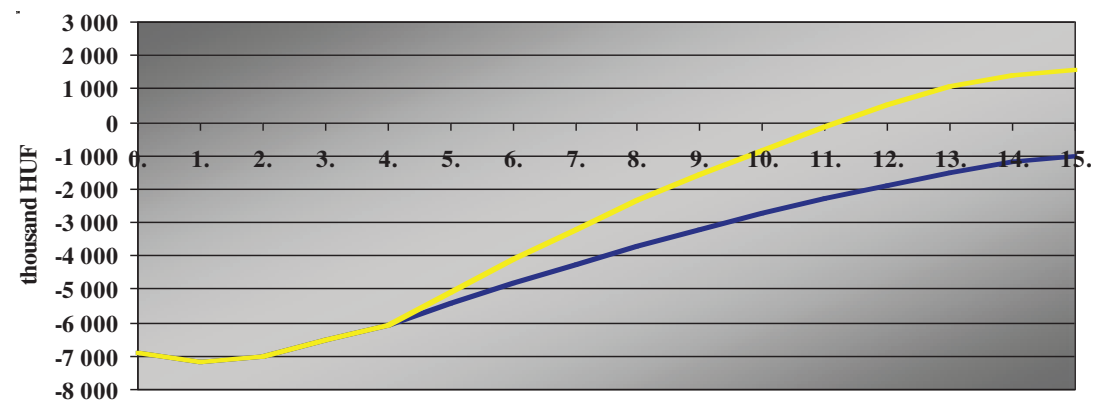

Age of the plantation (years)

- Mean yield during the fruiting years: $40 \mathrm{t} / \mathrm{ha}$ Mean yield during the fruiting years: $50 \mathrm{t} / \mathrm{ha}$

Figure 2. Economy and returns of plantations equipped with hail protecting nets without subsidy given for investment (net incomes on the present value are accumulated (NPV) expressed in 
In Figure 2, the calculation from above is presented. The costs of the net mean an additional sum on the original 4.5 million $\mathrm{Ft} / \mathrm{ha}$ resulting 7.0 million $\mathrm{Ft} / \mathrm{ha}$, i.e. increasing by roughly 3.5 million $\mathrm{Ft}$, but the costs of the supporting system, roughly 1.0 million $\mathrm{Ft}$, could be spared, which moderates the increment of investment to 2.5 million Ft only.

Our calculations conclude that in apple plantations yielding $40 \mathrm{t} / \mathrm{ha}$, the investments of 7.0 million $\mathrm{Ft} / \mathrm{ha}$ never would be compensated within the 15 year long lifetime. Yields of $50 \mathrm{t} / \mathrm{ha}$ only might produce the return in the $12^{\text {th }}$ year; and the profitability proportional to the capital (IRR) will be $9.7 \%$, which approaches the level of acceptability.

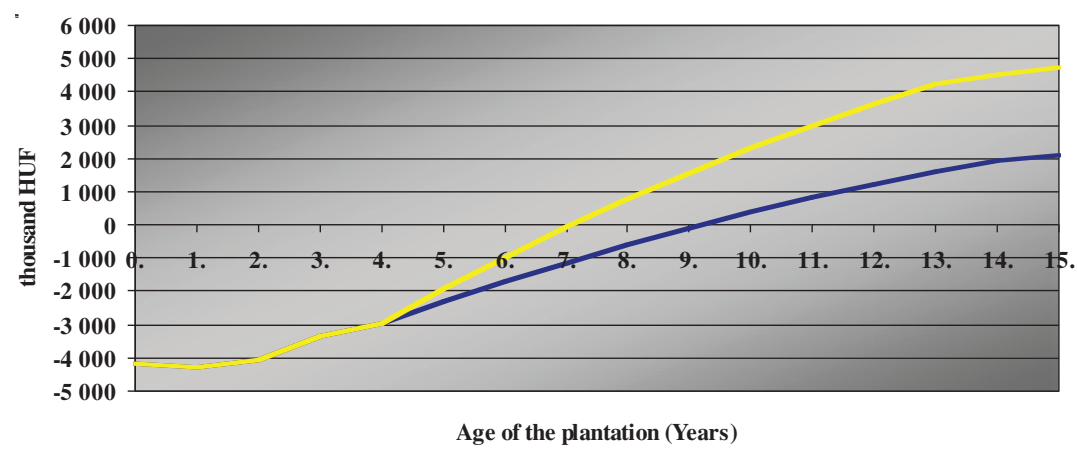

- Mean yield during the fruiting years: $40 \mathrm{t} / \mathrm{ha}$

Figure 3. Economy and returns of plantations equipped with hail protecting nets and subsidy given for investment (net incomes on the present value are accumulated, expressed in thousand $\mathrm{Ft} / \mathrm{ha}$ )

In Figure 3, the data of Figure 2 are utilised with the difference that $40 \%$ subvention is added to the investment. The economy of the enterprise is improved also with the 40 t/ha yields, but the 7 year long period will be prolonged until

Table 1. Economic judgment of hail protecting nets and that of plantations equipped with hail nets

\begin{tabular}{|c|c|}
\hline $\begin{array}{c}\text { Economy of plantations equipped } \\
\text { with hail protecting nets }\end{array}$ & Economy of hail protecting nets \\
\hline Costs: & Costs: \\
\hline $\begin{array}{l}\text { - investments (planting and } \\
\text { training, tending before the start } \\
\text { of fruiting and the construction } \\
\text { of hail net altogether, 7-10 } \\
\text { million Ft/ha) } \\
\text { - costs during the fruiting period }\end{array}$ & $\begin{array}{l}\text { - investments of construction (2.5- } \\
4.0 \text { million Ft/ha) } \\
\text { - costs yearly (during the fruiting } \\
\text { period opening and closing of the } \\
\text { net, maintenance roughly 10-30 } \\
\text { thousand Ft/ha/year) }\end{array}$ \\
\hline Yields and incomes: & Yields and incomes: \\
\hline $\begin{array}{l}\text { - incomes of fruit production } \\
\text { (profits), which is the difference } \\
\text { between the incomes and the } \\
\text { production costs, yearly }\end{array}$ & $\begin{array}{l}\text { - "saved incomes" fro the actual } \\
\text { and occasional damages caused } \\
\text { by hails }\end{array}$ \\
\hline Criterion of returns: & Criterion of returns: \\
\hline $\begin{array}{l}\text { the yearly earnings have to } \\
\text { produce the investment costs of } \\
\text { the hail protecting nets, at least }\end{array}$ & $\begin{array}{l}\text { - the saved incomes (which are } \\
\text { diminished by minor costs, } \\
\text { yearly actual) of the investment } \\
\text { of the construction of the hail } \\
\text { protective net }\end{array}$ \\
\hline
\end{tabular}

the $10^{\text {th }}$ year with $20.2 \%$ as profitability proportional to the capital invested (IRR) declines to $12.8 \%$ because of the additional 2.5 million $\mathrm{Ft} / \mathrm{ha}$ cost.

In our calculations, it is clearly visible that the economy of the hail protecting net ought to be estimated separately entirely from that of the plantation. As a proof, we show the details of Table 1 .

The utility of the hail protecting nets is essentially the "the income saved" from occasional damages caused by hail, which is paid in advance with the additional investment, roughly $2.5-4.0$ million $\mathrm{Ft} / \mathrm{ha}$. The utility of the plantation equipped by hail protecting net and yielding $40 \mathrm{t} / \mathrm{ha}$ fruit during the fruiting period ought to be compared with total investment costs, 7.0-10.0 million $\mathrm{Ft} / \mathrm{ha}$. Income means in that case the value earned by sales, which amounts in a modern plantation 500-900 thousand Ft/ha, which ought to be calculated on the present value. It expresses the interests required by the capital invested.

A highly important economic consequence is that the value of the turnover is not changed by the "saved income" if hail net was involved compared with a plantation without hail nets as well as without hail damage. It would happen that - e.g. in a plantation with $40 \mathrm{t} / \mathrm{ha}$ yields, the value of investment is equalled because heavy hails occurred and the saved income could be more than the costs of the hail net, moreover the 2.5-4.0 million $\mathrm{Ft}$ investment. However, the plantation with hail protecting nets as a growing system cannot be justified with $40 \mathrm{t} / \mathrm{ha}$ yields, which means yearly 500-900 thousand Ft/ha circulation (which cannot be increased by applying hail nets) we ought to subtract the interests of the locked up capital too, thus 7.0-10.0 million Ft. Plantations with 40 t/ha yields never will be able to reproduce the costs of investment.

Our calculations proved that plantations yielding 30-40 t/ha per year equipped with hail protecting nets will not be profitable during their lifetime as the investments mean 7.0-10.0 million Ft/ha. Therefore the use of hail nets need to yield more than 50-60 t/ha. Planning of new plantations ought to consider this precondition. If an existing plantation is to be equipped with hail net, the planning had to deal with the investment of the hail net only. The plantation costs are already realised. Then, we have to start with the supposition that hails will occur (e.g. with frequencies of 3, 2 or even 1 or every year) and may cause damages, which produces high sums of "saved income" will amount more than the costs of the hail net. All the same, the decision may be considered as justified, but the whole investment still not. We have to remark that is many plantations of fruit growers in Hungary, the application of hail protective nets is not a question of economy, but difficulties of financing are arising.

Acknowledgement The research has been sponsored by National Fund of Technological Develeopment on the number TECH 08-A4/2-2008-0138 